\title{
Displacement of lead from polluted top soil by treatment with $\mathrm{HCl}$ or $\mathrm{FeCl}_{3}$
}

\author{
M. Hooghiemstra-Tielbeek, M. G. Keizer and F. A. M. de Haan
}

Department of Soil Science and Plant Nutrition, Agricultural University, Wageningen, Netherlands

Key-words: lead, soil pollution, soil treatment, extraction, acidification, displacement, $\mathrm{HCl}, \mathrm{FeCl}_{3}$, lead chloride complexes

\section{Summary}

A major problem associated with soil lead pollution is the direct ingestion of contaminated soil by small children. To reduce this uptake the lead content of the top soil should be decreased.

Since acidification of soil increases the solubility of lead, treatment of lead-polluted soils with acid followed by application of water, brings about a reduction in the lead content of the top soil layer. For reasons of effectivity, $\mathrm{pH}$ has to be decreased to values as low as 2.5-3. Chloride is to be preferred as accompanying anion, because it promotes extraction due to formation of soluble lead chloride complexes.

Determination of the titration curve of the polluted soil and thickness of the top soil layer which has to be treated, allow calculation of the quantity of acid required to reach a sufficiently low $\mathrm{pH}$. The amount of lime required after treatment to readjust $\mathrm{pH}$ to a level compatible with plant growth can be calculated in the same way. The titration curve of the sub soil allows estimation of the depth where applied acid becomes neutralized and dissolved lead is bound again onto the solid phase.

In a lysimeter experiment, treatment with $\mathrm{HCl}$ and $\mathrm{FeCl}_{3}$ resulted in a reduction of the total lead content in the top $10 \mathrm{~cm}$ by 77 and $66 \%$ respectively, without causing lead to leach beyond a depth of ca. $50 \mathrm{~cm}$. Treatment with $\mathrm{FeCl}_{3}$ increases the phosphate sorption capacity of the soil.

\section{Introduction}

The high costs involved in removal of polluted soil and its replacement with uncontaminated mould have aroused interest in the development of methods aimed at the cleaning of polluted soil in situ.

In case of heavy metal pollution it is often unnecessary to lower the metal content of the soil, because undesirable effects may be suppressed by immobilization of the metal in the soil. In many cases this can be achieved simply by raising the $\mathrm{pH}$ of the soil. In other cases application of metal-binding materials such as organic matter may be required additionally. 
Pollution of soil with lead, however, cannot always be dealt with in this way. A major problem associated with lead pollution is direct ingestion of contaminated soil by children, which may cause their total lead uptake to attain health-damaging levels. Immobilization of lead in the soil will not reduce uptake via this pathway, because the metal will be remobilized in the human stomach. A reduction in the lead content of the top soil, on the other hand, will constitute a real improvement in such situations.

In a residential quarter of Arnhem, Netherlands, top soils have become contaminated with lead originating partly from a secondary lead smelter close by and partly from traffic (Keizer et al., 1982). Here young children have elevated lead levels in their blood, close to the acceptable maximum. Uptake of contaminated soil and house dust was shown to contribute significantly to their lead intake (Brunekreef et al., 1981). With respect to this situation in Arnhem, several methods aimed at diminishing the lead content of the top soil layer $(0-20 \mathrm{~cm})$ have been studied (Hooghiemstra-Tielbeek, 1981).

This paper deals with soil acidification as a possible means for displacement of lead within a soil profile. Lead solubility can be increased by lowering soil $\mathrm{pH}$, entailing dissolution of sparingly soluble lead minerals, exchange from the adsorption complex and reduced complexation by organic matter.

In Japan treatment with $0.1 \mathrm{~mol} / \mathrm{HCl}$ has been applied in practice in order to diminish cadmium pollution of rice fields. Extraction effectivity was not high (ca. $22 \%$ ) probably because of a relatively high soil $\mathrm{pH}$ during treatment (Takyina et al., 1973).

When considering soil treatment one has to evaluate removal effectivity, practical applicability and possible impact on the environment. In the case of lead removal from the soil solid phase by acidification, effectivity will depend on factors like: attained soil $\mathrm{pH}$ value, chemical forms of lead present in the soil and the formation of soluble lead complexes. The quantity of acid required depends on the neutralization capacity of the soil and thus on the content of clay minerals, organic matter, carbonates and (hydr)oxides (buffering capacity). Acidification with $\mathrm{HCl}$ or $\mathrm{FeCl}_{3}$ seems to be particularly attractive because chloride will enhance lead solubility as the result of formation of lead chloride complexes.

Practical applicability depends on the characteristics of the chemicals involved and on the labour and material costs. Application of concentrated acid as a liquid, for example, can be harmful because of the formation of toxic vapours. The treatment should not cause pollution of groundwater with lead or other dissolved toxic elements. In addition, it should not bring about irreversible changes in the soil rendering it unsuitable as a medium for plant growth. Evidently, soil $\mathrm{pH}$ has to be readjusted after treatment to an appropriate level, but other disadvantageous effects (e.g. on availability of phosphorus and micronutrients) also have to be considered.

\section{Materials and methods}

Soils used in the experiments were mainly lead-polluted soils from Arnhem and in some cases reference soils from the Department of Soil Science and Plant Nutri- 
tion. Total concentrations of dissolved $\mathrm{Pb}, \mathrm{Fe}$ and $\mathrm{Zn}$ were measured by atomic absorption spectrophotometry after filtration through a hard ash-free filter. Total $\mathrm{Pb}$, $\mathrm{Fe}$ and $\mathrm{Zn}$ contents of the soils were determined by extracting $5 \mathrm{~g}$ of air-dried soil with $40 \mathrm{~cm}^{3} 3 \mathrm{~mol} / \mathrm{l} \mathrm{HCl}$ for 3 hours in a boiling water bath. After extraction volume was made up to $100 \mathrm{~cm}^{3}$ with de-ionized water. Total carbonate content of the soils was determined according to Scheibler (Houba et al., 1979). pH was measured with a glass electrode and $\mathrm{KCl}$-saturated calomel electrode. Phosphate concentrations in solution were determined according to Murphy \& Riley (1962).

Three types of experiments were performed: batch, column and lysimeter experiments.

\section{Batch experiments}

- Determination of the buffering capacity by shaking $20 \mathrm{~g}$ of air-dried soil during $20 \mathrm{~h}$ with $50 \mathrm{~cm}^{3} 1 \mathrm{~mol} / \mathrm{KCl}$ including different amounts of $\mathrm{HCl}$. The supernatant was analysed for $\mathrm{pH}$ and dissolved lead.

- Determination of the neutralization capacity of acidified soil by shaking $10 \mathrm{~g}$ of air-dried soil during $20 \mathrm{~h}$ with $25 \mathrm{~cm}^{3} 1 \mathrm{~mol} / 1 \mathrm{KCl}$ including different amounts of $\mathrm{KOH}$. pH was measured in the supernatant.

- Determination of the binding of dissolved lead from an acid solution to soil by shaking $10 \mathrm{~g}$ of air-dried soil during some time (from $2 \mathrm{~h}$ till several days) with 25 $\mathrm{cm}^{3} 1 \mathrm{~mol} / \mathrm{KCl}+1 \mathrm{mmol} / 1 \mathrm{~Pb}\left(\mathrm{NO}_{3}\right)_{2}+\mathrm{HNO}_{3}$ or $\mathrm{FeCl}_{3}$. The supernatant was analysed for lead and $\mathrm{pH}$.

- Determination of the phosphate sorption isotherm before and after treatment of the soil. A batch of $5 \mathrm{~g}$ of air-dried soil was shaken for $20 \mathrm{~h}$ with $50 \mathrm{~cm}^{3} 0.01 \mathrm{~mol} / \mathrm{l}$ $\mathrm{CaCl}_{2}$ including different amounts of $\mathrm{KH}_{2} \mathrm{PO}_{4}$. The supernatant was analysed for total phosphate and $\mathrm{pH}$. This method gives a rough estimate only of phosphate sorption. The soil treatments involved were: acidification with $\mathrm{FeCl}_{3}$ or $\mathrm{HCl}$ to $\mathrm{pH}$ 2.5 followed by liming with $\mathrm{Ca}(\mathrm{OH})_{2}$. Soil was mixed with acid and kept at field capacity during $24 \mathrm{~h}$, then rinsed with tap water till a sufficient low conductivity was reached $(<1 \mathrm{~S} / \mathrm{m})$. Part of the soil thus treated was limed with $\mathrm{Ca}(\mathrm{OH})_{2}$ to $\mathrm{pH} 6.5$. The amount of acid or base required to obtain the desired $\mathrm{pH}$ value was derived from the titration curve of the soil. Phosphate sorption isotherms were determined after incubation of the treated soils at field capacity for 2 weeks.

\section{Column experiments}

- Three different ways of application of $\mathrm{FeCl}_{3}$ were studied: in columns $(\mathrm{d}=1.9$ $\mathrm{cm}, \mathrm{h}=2.5 \mathrm{~cm}$ ) containing $10 \mathrm{~g}$ of air-dried soil solid or dissolved $\mathrm{FeCl}_{3}$ was mixed through the upper $5 \mathrm{~g}$ of soil; solid $\mathrm{FeCl}_{3}$ was also spread on the surface of the soil column. The $\mathrm{FeCl}_{3}$ solution consisted of solid $\mathrm{FeCl}_{3}$ dissolved in $10-25 \mathrm{~cm}^{3} 0.01$ $\mathrm{mol} / \mathrm{l} \mathrm{Ca}\left(\mathrm{NO}_{3}\right)_{2}$. The columns were then leached with $0.01 \mathrm{~mol} / \mathrm{Ca}\left(\mathrm{NO}_{3}\right)_{2}$ at a flow rate of $6 \mathrm{~cm}^{3} / \mathrm{h}$.

- Extraction effectivity of $\mathrm{HCl}$ treatment as compared to $\mathrm{FeCl}_{3}$ treatment was measured in different soils. For this purpose columns $(\mathrm{d}=1.9 \mathrm{~cm}, \mathrm{~h}=5 \mathrm{~cm})$ containing $20 \mathrm{~g}$ of air-dried soil were treated with $\mathrm{HCl}$ of $\mathrm{FeCl}_{3} . \mathrm{HCl}$ and $\mathrm{FeCl}_{3}$ were dissolved in $5.6 \mathrm{~cm}^{3}$ water. The amounts of acid required to bring $\mathrm{pH}$ to a value of 


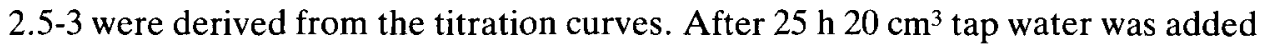
and the effluent analysed for lead and $\mathrm{pH}$.

- Leaching of lead from the top layer and fixation at greater depth was studied by using taller soil columns $(\mathrm{d}=3 \mathrm{~cm}, \mathrm{~h}=40 \mathrm{~cm})$. Three mmol of solid $\mathrm{FeCl}_{3}$ was mixed through the upper $2 \mathrm{~cm}$ of the soil. Soil columns were then leached with 0.01 $\mathrm{mol} / \mathrm{l} \mathrm{Ca}\left(\mathrm{NO}_{3}\right)_{2}$ for 3 months with an average flow rate of $1 \mathrm{~mm} /$ day. Composition of the soil columns was as follows: $0-4 \mathrm{~cm}: 10 \mathrm{~g}$ of air-dried soil A-3 (buffering capacity of $67 \mathrm{mmol} \mathrm{FeCl} / 3 \mathrm{~kg}$ ) mixed with $10 \mathrm{~g}$ of quartz sand; $4-40 \mathrm{~cm}: 120 \mathrm{~g}$ of airdried soil A-3 mixed with $80 \mathrm{~g}$ of quartz sand or of other reference soils also mixed with quartz sand to a total weight of $200 \mathrm{~g}$. Soils were brought at field capacity before treatment started.

\section{Lysimeter experiment}

Determination of the effectivity of $\mathrm{HCl}$ and $\mathrm{FeCl}_{3}$ treatment at semi-practical conditions was studied in a lysimeter experiment. Two lysimeters $(\mathrm{d}=150 \mathrm{~cm}, \mathrm{~h}=80$ $\mathrm{cm}$ ) were filled with 3 types of soil (cf. Table 1). The layer $0-10 \mathrm{~cm}$ was treated with $\mathrm{HCl}$ or $\mathrm{FeCl}_{3}$. The amount of acid required to bring $\mathrm{pH}$ to a value of 2.5-3 over the complete layer $0-10 \mathrm{~cm}$, was derived from the titration curve of the top soil (A-14). During the experiment it appeared that the $\mathrm{pH}$ had not been decreased sufficiently causing low extraction of lead. Therefore the same amount of acid was applied a second time. After each acid application the soil was leached with water during several days. Treatment details are given in Table 2 . At the end of the experiment both soil profiles were sampled in $10-\mathrm{cm}$ layers. Samples were analysed for total $\mathrm{Pb}$ and $\mathrm{Zn}$. Also the effluent of the lysimeters was analysed for total dissolved $\mathrm{Pb}$.

\section{Results and discussion}

\section{Batch experiments}

Titration curves and carbonate content of soils were measured in order to derive the amount of acid required to decrease the soil $\mathrm{pH}$ to a certain value. The equivalent amounts of $\mathrm{FeCl}_{3}$ were based on the assumption that $1 \mathrm{~mol} \mathrm{FeCl}{ }_{3}$ can deliver 3 mol $\mathrm{H}$. Because of incomplete hydrolysis addition of $\mathrm{FeCl}_{3}$ resulted in somewhat

Table 1. Characteristics of the soils* used in the lysimeter experiment.

\begin{tabular}{llll}
\hline & A-14 & A-18 & Enggrond \\
total $\mathrm{Pb}(\mathrm{mg} / \mathrm{kg})$ & 1310 & 171 & 62 \\
total $\mathrm{Zn}(\mathrm{mg} / \mathrm{kg})$ & 540 & 115 & 30 \\
depth $(\mathrm{cm})$ & $0-10$ & $10-20$ & $20-80$ \\
pH-KCl & 6.1 & 7.3 & 4.7 \\
Carbonate content $\left(\% \mathrm{CaCO}_{3}\right)$ & 0.1 & 2.0 & - \\
Quantity of acid required to & & & \\
reach $\mathrm{pH} 2.5(\mathrm{mmol} \mathrm{H} / \mathrm{kg})$ & 120 & 600 & 210
\end{tabular}

\footnotetext{
* A-14 and A-18 are soils from Arnhem; one of the reference soils is Enggrond, a slightly loamy, medium coarse textured, gravelly sand.
} 
Table 2. Some details of the $\mathrm{HCl}(\mathrm{A})$ and $\mathrm{FeCl}_{3}(\mathrm{~B})$ treatment in the lysimeter experiment.

\begin{tabular}{|c|c|c|c|c|}
\hline Application & $\begin{array}{l}\text { Total } \\
\text { volume }\left(\mathrm{dm}^{3}\right)\end{array}$ & $\begin{array}{l}\text { Contact } \\
\text { time (day) }\end{array}$ & $\begin{array}{l}\text { Application } \\
\text { period (day) }\end{array}$ & $\begin{array}{l}\text { Averaged percolation } \\
\text { rate }(\mathrm{mm} / \text { day })\end{array}$ \\
\hline \multicolumn{5}{|l|}{$A$} \\
\hline $1 \mathrm{HCl} 2 \mathrm{~mol} / \mathrm{l}$ & 12.5 & 4 & & \\
\hline 2 water & 25 & & 1 & \\
\hline 3 water & 185 & & 28 & 3.7 \\
\hline $4 \mathrm{HCl} 2 \mathrm{~mol} / \mathrm{l}$ & 12.5 & 4 & & \\
\hline 5 water & 23 & & 1 & \\
\hline 6 water & 273 & & 42 & 3.2 \\
\hline \multicolumn{5}{|l|}{$B$} \\
\hline $1 \mathrm{FeCl}_{3} 0.7 \mathrm{~mol} / 1$ & 12.5 & 3 & & \\
\hline 2 water & 25 & & 1 & \\
\hline 3 water & 224 & & 49 & 2.6 \\
\hline $4 \mathrm{FeCl}_{3} 0.7 \mathrm{~mol} / 1$ & 12.5 & 1 & & \\
\hline 5 water & 25 & & 1 & \\
\hline 6 water & 334 & & 14 & 13.5 \\
\hline
\end{tabular}

higher soil $\mathrm{pH}$ values than the $\mathrm{HCl}$ treatment (cf. also Table 5).

For most soils $\mathrm{pH}$ values lower than ca. 2.5 could not be obtained with $\mathrm{FeCl}_{3}$. The amount of acid for lowering the $\mathrm{pH}$ to a value of ca. 2.5 varied for the soils studied between $0.1-0.5 \mathrm{~mol} \mathrm{H} / \mathrm{kg}$ when neglecting the carbonate content, and between $0.1-1.0 \mathrm{~mol} \mathrm{H} / \mathrm{kg}$ when taking carbonate content into account $(0.2 \mathrm{~mol} \mathrm{H} / \mathrm{kg}$ soil for $1 \% \mathrm{CaCO}_{3}$ ).

While determining the titration curves also lead extraction was measured. As an example the results of one soil are presented in Fig. 1. The amount of lead extracted was strongly correlated with the $\mathrm{pH}$ of the system. At pH $2.5,45-65 \%$ of total lead in the soil was extracted. Because of the high chloride concentration (1 $\mathrm{mol} / \mathrm{l} \mathrm{KCl}$ ) almost all dissolved lead was presumably present as complexes with chloride (cf. Table 3).

The lead dissolved in the top layer of the soil must be removed again from solution to the solid phase in lower soil layers. Fixation of lead from an acid solution is possible only when the acid has been neutralized. Knowing the buffering capacity of the soil one may calculate the depth at which the added amount of acid will be neutralized.

When soils will be used after treatment for plant growth, soil $\mathrm{pH}$ of the top layer must brought back to an appropriate value by liming. In order to determine the amount of base required for this purpose, titration curves of the treated soils were measured by base addition. From these experiments it appeared that acid treatment caused a small decrease in buffering capacity for both $\mathrm{HCl}$ and $\mathrm{FeCl}_{3}$ treatments.

Experiments performed at $\mathrm{pH} 2.5$ and different chloride concentrations $(0.02-$ $0.8 \mathrm{~mol} / \mathrm{l} \mathrm{Cl}$ ) revealed that lead extraction is favoured by high chloride concentra- 


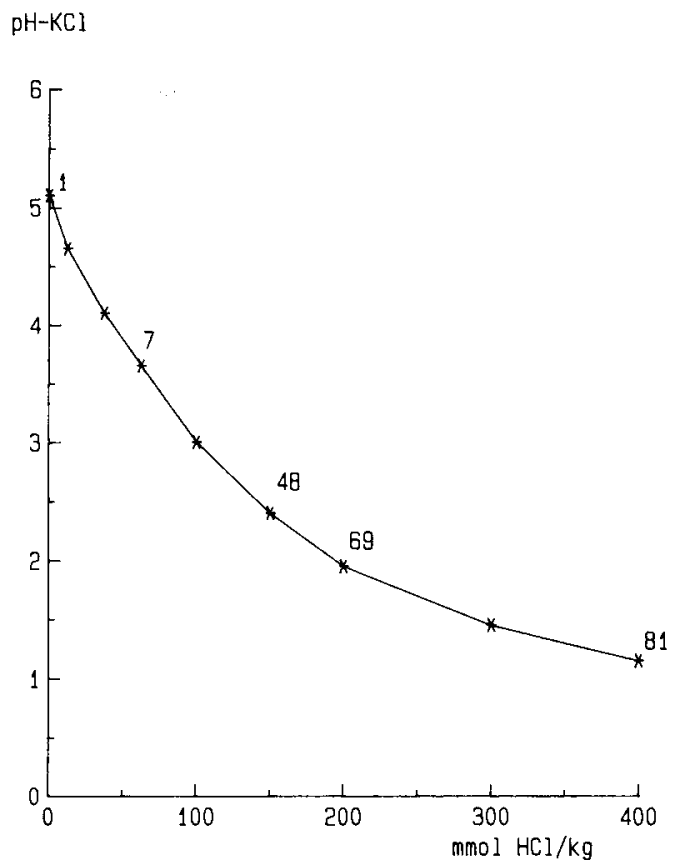

Fig. 1. Titration curve of soil A-3 measured in $1 \mathrm{~mol} / 1 \mathrm{KCl}$. Figures indicated are \% of lead extracted from the soil.

tions. Hahne \& Kroontje (1973) already discussed the effect of formation of lead chloride complexes on the mobility of lead in soil. The formation of these complexes depends mainly on ionic strength and total chloride concentration in solution as is shown in Table 3.

At high $\mathrm{pH}$ and high chloride and lead concentrations formation of the sparingly soluble $\mathrm{Pb}_{5}\left(\mathrm{PO}_{4}\right)_{3} \mathrm{Cl}$ (chloropyromorphite) could decrease extraction effectivity. Whether such precipitation will occur depends on the activities of $\mathrm{Pb}^{2+}, \mathrm{PO}_{4}^{3-}, \mathrm{Cl}$

Table 3. Calculated distribution (in \%) of total dissolved lead over $\mathrm{Pb}^{2+}$ and lead chloride complexes at different values for ionic strength, total chloride and total chloride/total lead ratios.

\begin{tabular}{lllllll}
\hline Ionic strength $(\mathrm{mol} / \mathrm{l})$ & $0^{1}$ & 1 & 1 & 1 & 0.01 & 0.01 \\
Total $\mathrm{Cl}(\mathrm{mol} / \mathrm{l})$ & 1 & 1 & 0.01 & 0.01 & 0.01 & 0.01 \\
Total $\mathrm{Cl}$ total $\mathrm{Pb}$ & 1000 & 1000 & 1000 & 10 & 10 & 1000 \\
$\mathrm{~Pb}^{2+}$ & 0.6 & 4.8 & 93.1 & 93.2 & 79.3 & 79.0 \\
$\mathrm{PbCl}^{+}(\operatorname{log~K}=1.6)^{2}$ & 23.1 & 35.1 & 6.9 & 6.8 & 20.4 & 20.8 \\
$\mathrm{PbCl}_{2}\left(\operatorname{log~K} \mathrm{K}^{0}=1.78\right)$ & 34.9 & 21.8 & - & - & 0.3 & 0.3 \\
$\mathrm{PbCl}_{3}^{-}\left(\operatorname{log~K} \mathrm{K}^{0}=1.68\right)$ & 27.6 & 17.3 & - & - & - & - \\
$\mathrm{PbCl}_{4}^{2-}\left(\operatorname{log~K} \mathrm{K}^{0}=1.38\right)$ & 13.8 & 21.0 & - & - & - & - \\
\hline
\end{tabular}

1 Distribution calculated with $\log \mathrm{K}^{0}$ without correction for ionic strength.

$2 K^{0}=$ formation constant at zero ionic strength. Values for $\log K^{0}$ are obtained from Lindsay (1979). Correction for ionic strength (I) was made by calculating activity coefficients with the Davies equation at $\mathrm{I} \leqslant 0.5 \mathrm{~mol} / \mathrm{l}$ and the modified Helgeson equation at $\mathrm{I}>0.5 \mathrm{~mol} / \mathrm{l}$ (Sposito \& Mattigod, 1979). 
Table 4. Phosphate sorption maximum according to the Langmuir adsorption equation and $\mathrm{pH}-\mathrm{KCl}$ values of soil A-5 after different treatments.

\begin{tabular}{lll}
\hline Treatment & $\mathrm{pH} \cdot \mathrm{KCl}$ & Sorption maximum (mg P/kg) \\
& & \\
Not treated & 6.6 & 230 \\
$\mathrm{FeCl} 100 \mathrm{mmol} / \mathrm{kg}$ & 3.2 & 600 \\
$\mathrm{FeCl}_{3} 100 \mathrm{mmol} / \mathrm{kg}+\mathrm{Ca}(\mathrm{OH})_{2}$ & 6.3 & 440 \\
$\mathrm{HCl} 300 \mathrm{mmol} / \mathrm{kg}$ & 2.8 & 240 \\
$\mathrm{HCl} 300 \mathrm{mmol} / \mathrm{kg}+\mathrm{Ca}(\mathrm{OH})_{2}$ & 6.5 & 220 \\
\hline
\end{tabular}

and $\mathrm{H}^{+}$and on the kinetics of the precipitation reaction. Adsorption of $\mathrm{PbCl}^{+}$to oxide surfaces (Barrow et al., 1981) may decrease solubility too. Under experimental conditions of high total chloride concentration, high ionic strength and low $\mathrm{pH}$, adsorption of negatively charged lead chloride complexes also may contribute to lead fixation. At this moment no data are available to evaluate these effects.

With $\mathrm{FeCl}_{3}$ treatment considerable quantities of iron are added to the soil, which may enhance sorption of phosphate (cf. Table 4). Liming with $\mathrm{Ca}(\mathrm{OH})_{2}$ reduces this effect. Treatment with $\mathrm{HCl}$ had no substantial effect on phosphate sorption of the soil studied.

\section{Column experiments}

Extraction effectivity of $\mathrm{FeCl}_{3}$ might be influenced by application in dissolved or solid form. Solid $\mathrm{FeCl}_{3}$ can be mixed through the top soil layer or be spread on the soil surface. From the experimental results it appeared that the amount of lead extracted is about the same for all 3 cases. Application of $\mathrm{FeCl}_{3}$ in solid form caused an earlier start of lead leaching as compared to application in dissolved form, probably due to a temporarily lower $\mathrm{pH}$ and higher chloride concentration. A lower percola-

Table 5. Results of $\mathrm{Pb}$ extraction by $\mathrm{HCl}$ and $\mathrm{FeCl}_{3}$ treatment for several soils (column exp.).

\begin{tabular}{|c|c|c|c|c|c|c|}
\hline \multirow[t]{2}{*}{ Soil } & \multirow[t]{2}{*}{ Acid } & \multirow{2}{*}{$\begin{array}{l}\text { Amount added } \\
(\mathrm{mmol} / \mathrm{kg})\end{array}$} & \multirow{2}{*}{$\mathrm{pH}-\mathrm{KCl}$} & \multicolumn{2}{|c|}{$\mathrm{Pb}$ content $(\mathrm{mg} / \mathrm{kg})$} & \multirow{2}{*}{$\begin{array}{l}\text { Pb extraction } \\
(\%)\end{array}$} \\
\hline & & & & $\begin{array}{l}\text { before } \\
\text { treatment }\end{array}$ & $\begin{array}{l}\text { after } \\
\text { treatment }\end{array}$ & \\
\hline \multirow[t]{2}{*}{ A-3 } & $\mathrm{FeCl}_{3}$ & 67 & 3.5 & 401 & 357 & 11 \\
\hline & $\mathrm{HCl}$ & 200 & 2.9 & & 345 & 14 \\
\hline \multirow[t]{2}{*}{ A-6 } & $\mathrm{FeCl}_{3}$ & 67 & 3.3 & 496 & 437 & 12 \\
\hline & $\mathrm{HCl}$ & 200 & 2.7 & & 427 & 14 \\
\hline \multirow[t]{2}{*}{ A-14 } & $\mathrm{FeCl}_{3}$ & 27 & 3.7 & 1310 & 865 & 34 \\
\hline & $\mathrm{HCl}$ & 80 & 3.4 & & 812 & 38 \\
\hline \multirow[t]{2}{*}{ A-15 } & $\mathrm{FeCl}_{3}$ & 127 & 3.9 & 422 & 359 & 15 \\
\hline & $\mathrm{HCl}$ & 380 & 3.0 & & 295 & 30 \\
\hline \multirow[t]{2}{*}{ A-16 } & $\mathrm{FeCl}_{3}$ & 127 & 3.5 & 433 & 342 & 21 \\
\hline & $\mathrm{HCl}^{3}$ & 380 & 3.0 & & 277 & 36 \\
\hline \multirow[t]{2}{*}{ A-17 } & $\mathrm{FeCl}_{3}$ & 160 & 3.6 & 374 & 296 & 21 \\
\hline & $\mathrm{HCl}$ & 480 & 2.9 & & 243 & 35 \\
\hline
\end{tabular}


tion rate $\left(1 \mathrm{~cm}^{3} / \mathrm{h}\right)$ yielded some different results depending on soil type. A long contact time is only favourable for lead extraction when $\mathrm{pH}$ remains low enough. When $\mathrm{pH}$ increases by neutralization, a low flow rate gives more opportunity for fixation of previously dissolved lead.

To compare extraction effectivity of $\mathrm{HCl}$ and $\mathrm{FeCl}_{3}$ column experiments were performed with both treatment methods for several soils (cf. Table 5). With $\mathrm{HCl}$ more lead was extracted, probably due to a lower soil $\mathrm{pH}$. Apparently it is difficult to calculate the amount of $\mathrm{FeCl}_{3}$ required to obtain the same soil $\mathrm{pH}$ as with $\mathrm{HCl}$. As can be deduced from the results lead extraction is rather low (11-38\%) and differs strongly from soil to soil. This variation can be explained partly from the occurrence of different forms of lead in the soils, all with different $\mathrm{pH}$ dependancy, and by different soil $\mathrm{pH}$ values obtained by the treatments.

Other column experiments were set up to evaluate if dissolution of lead in the top
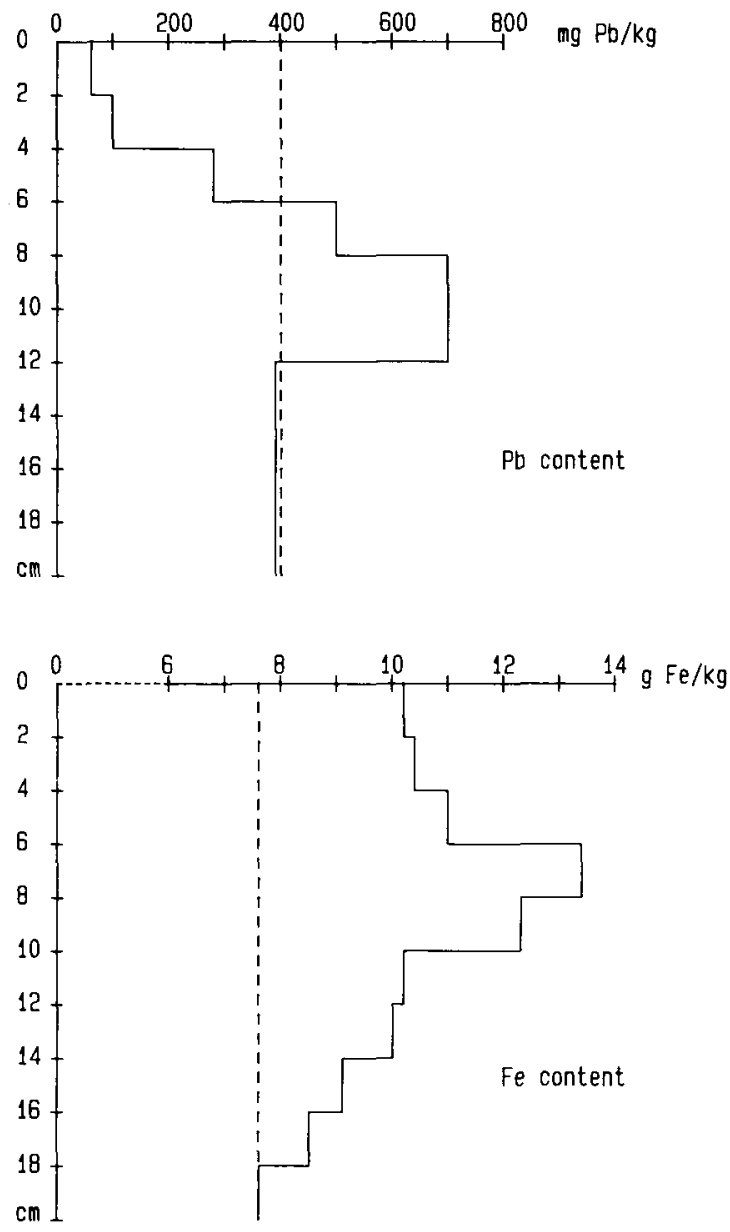

Fig. 2. $\mathrm{Pb}$ and $\mathrm{Fe}$ concentrations $(\mathrm{mg} / \mathrm{kg}$ ) in a soil column (soil A-3) after treatment with $3 \mathrm{mmol} \mathrm{FeCl}_{3}$ and leaching with $0.01 \mathrm{~mol} / 1 \mathrm{Ca}\left(\mathrm{NO}_{3}\right)$, during 3 months (averaged percolation rate 1 $\mathrm{mm}$ /day). . - : before treatment; _-: after treatment. 
soil layer will be followed by fixation of lead at a certain predicted depth. This depth can be calculated from the buffering capacity of the soil. Fig. 2 shows the results of such an experiment. For the soil studied (A-3) the amount of acid $\left(\mathrm{FeCl}_{3}\right)$ added in order to decrease the $\mathrm{pH}$ to $\mathrm{ca} .2 .5$ in the soil layer $0-4 \mathrm{~cm}$ should be neutralized at a depth of ca. $10.5 \mathrm{~cm}$. At that depth lead and iron have been bound onto the solid phase indeed. In this case $75 \%$ of total lead was extracted from the top soil layer $(0-4 \mathrm{~cm})$. Displacement of lead to a greater depth, as will be desired for practical situations, can be achieved by adding more acid.

\section{Lysimeter experiment}

The results of this experiment are presented in Fig. 3. For both treatments $(\mathrm{HCl}$ and $\mathrm{FeCl}_{3}$ ) no lead was found in the effluent of the 2 lysimeters. With $\mathrm{HCl} 77 \%$ and with $\mathrm{FeCl}_{3} 66 \%$ of total lead was displaced from the layer $0-10 \mathrm{~cm}$. This high extraction could be achieved by adding 2 times the amount of acid required to obtain a $\mathrm{pH}$ value of $2.5-3$ in the soil layer $0-10 \mathrm{~cm}$, according to the titration curve. A higher dose was necessary because after treatment it appeared that the layer $5-10 \mathrm{~cm}$ was not sufficiently acidified, probably due to some mixing during the application operation with soil A-18 in the layer $10-20 \mathrm{~cm}$, with a very high buffering capacity.

To evaluate possible leaching of other heavy metals also total zinc content was measured. $\mathrm{HCl}$ and $\mathrm{FeCl}_{3}$ extracted $80 \%$ and $60 \%$ of total zinc in the layer $0-10$ $\mathrm{cm}$ respectively. Solubility of zinc is higher than of lead, which is confirmed by greater depth of fixation of zinc $(20-50 \mathrm{~cm})$ than of lead $10-30 \mathrm{~cm}$ (cf. Fig. 3). Thus acidification of the soil will cause leaching of micronutrients. Total mass balance for lead and zinc gave different results: 20-30\% loss of lead and 4-8 \% excess of zinc was found. This can partly be explained from soil heterogenity, analytical errors and perhaps from mixing of the soil layers $0-10 \mathrm{~cm}$ and $10-20 \mathrm{~cm}$ during treatment.

\section{Conclusions}

As lead solubility increases strongly with decreasing soil $\mathrm{pH}$, it is possible to remove lead from polluted soil by acidification. Since chloride enhances lead solubility through the formation of lead chloride complexes, acid treatment can best be done with $\mathrm{HCl}$ or $\mathrm{FeCl}_{3}$. In order to achieve a high extraction effectivity a low soil $\mathrm{pH}$ is required ( $\mathrm{pH} 2.5-3)$.

To displace lead from the top soil, layer thickness and buffering capacity have to be determined in order to calculate the amount of acid to be applied. From the buffering capacity of the subsoil one may calculate the depth at which the added amount of acid will be neutralized. At that depth fixation of lead and other dissolved heavy metals takes place. In this way one can induce displacement of lead within the soil profile without causing leaching to the groundwater.

At semi-practical conditions in a lysimeter $77 \%$ and $66 \%$ of total lead was displaced from the layer $0-10 \mathrm{~cm}$ by treatment with $\mathrm{HCl}$ and $\mathrm{FeCl}_{3}$ respectively, but no lead was detected in the effluent.

Before an acid-treated soil can be planted succesfully, $\mathrm{pH}$ has to be raised to a level compatible with plant growth. $\mathrm{In} \mathrm{FeCl}_{3}$-treated soils special attention has to be 

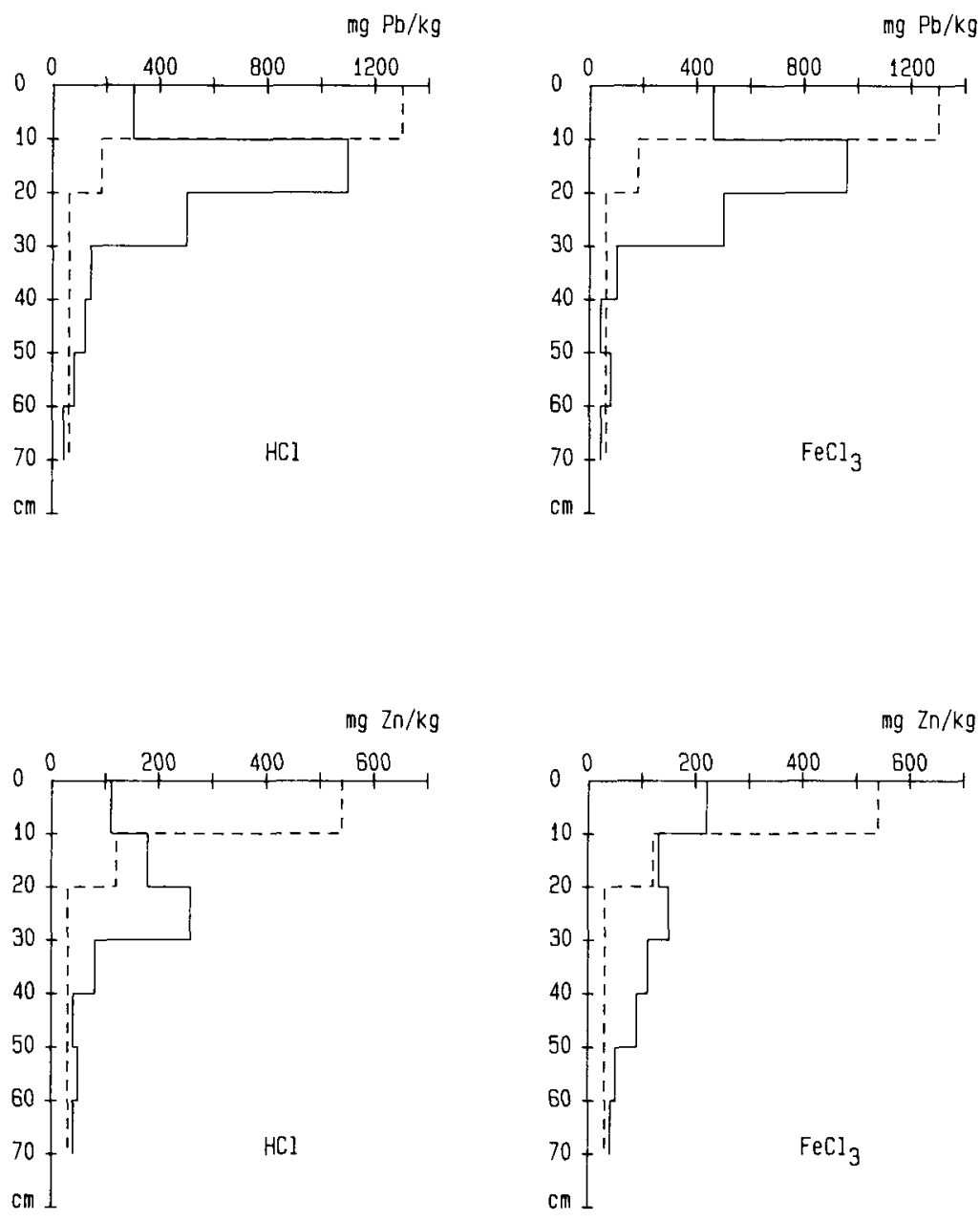

Fig. 3. Soil $\mathrm{Pb}$ and $\mathrm{Zn}$ concentrations $(\mathrm{mg} / \mathrm{kg}$ ) in the lysimeter experiment. Treatment of the soil layer $0-10 \mathrm{~cm}$ with $\mathrm{HCl}$ or $\mathrm{FeCl}_{3}$. ...: before treatment; —_: after treatment.

paid to the phosphate supply of the plants, since this treatment increases the phosphate sorption capacity of the soil considerably. Besides, the acid treatments might lead to a depletion of micronutrient reserves in the soil.

\section{Acknowledgements}

This study was supported by a grant from the Municipality of Arnhem. The authors are indebted to Ms. W. van Vark for performing the analyses involved. 


\section{References}

Barrow, N. J., J. W. Bowden, A. M. Posner \& J. P. Quirk, 1981. Describing the adsorption of copper, zinc and lead on a variabel charge mineral surface. Aust. J. Soil Res. 19: 309-321.

Brunekreef, B., S. J. Veenstra, K. Biersteker \& J. S. M. Boley, 1981. The Arnhem lead study. I. Lead uptake by 1 to 3-year-old children living in the vicinity of a secondary lead smelter in Arnhem, Netherlands. Environm. Res. 25: 441-448.

Hahne, H. C. H. \& W. Kroontje, 1973. Significance of $\mathrm{pH}$ and chloride concentration on behaviour of heavy metal pollutants: mercury (II), cadmium (II), zinc (II) and lead (II). J. environ. Quality 2(4): $444-450$.

Hooghiemstra-Tielbeek, M., 1981. De verwijdering van lood uit verontreinigde grond; Algemeen en technisch verslag. Vakgroep Bodemkunde en Bemestingsleer, LH, Wageningen.

Houba, V. J. G., J. Ch. van Schouwenburg \& I. Walinga, 1979. Method for soil analyses; Soil analyses. II. MSc course on soil science and water management. Agricultural University, Wageningen.

Keizer, M. G., M. Hooghiemstra-Tielbeek \& F. A. M. de Haan, 1982. Contamination of soil and street dust with lead and cadmium near a lead smelter at Arnhem, Netherlands. Neth. J. agric. Sci. 29: 227 235.

Lindsay, W. L., 1979. Chemical equilibria in soils. John Wiley, New York.

Murphy, J. \& J. P. Riley, 1962. A modified single solution method for the determination of phosphate in natural water. Analyt. chim. Acta 27: 31-36.

Sposito, G. \& S. V. Mattigod, 1979. Geochem: a computer program for the calculation of chemical equilibria in soil solutions and other natural water systems. Department of Soil and Environmental Sciences, University of California, Riverside.

Takyima, Y., F. Katsumi \& S. Koizumi, 1973. Cadmium contamination of soils and rice plants caused by zinc mining. V. Removal of soil cadmium by an $\mathrm{HCl}$-leaching method for the control of high Cd rice. Soil Sci. Plant Nutr. 19(4): 245-254. 